Original Article

\title{
Feeding habit of Brown trout (Salmo trutta fario) in upper parts of river Swat, Pakistan
}

\author{
Hábito de alimentação da truta marrom (Salmo trutta fario) nas partes superiores do \\ rio Swat, Paquistão
}

 \\ S. Akhtarg and M. Shadman ${ }^{\mathrm{a}}$ \\ aUniversity of Malakand, Department of Zoology, Lower Dir, Khyber Pakhtunkhwa, Pakistan \\ bSouthern Zone Agricultural Research Center - SARC, Outreach Research Activity Unit - ORAU, Karachi, Pakistan \\ 'University of Malakand, Department of Statistics, Lower Dir, Khyber Pakhtunkhwa, Pakistan \\ Islamia College University, Peshawar, Department of Zoology, Peshawar, Pakistan \\ eUniversity of Swabi, Department of Zoology, Swabi, Pakistan \\ ${ }^{\mathrm{f} K a r a k o r a m ~ I n t e r n a t i o n a l ~ U n i v e r s i t y ~ G i l g i t-B a l t i s t a n, ~ B i o l o g i c a l ~ S c i e n c e s ~ D e p a r t m e n t, ~ B i l t s t a n, ~ P a k i s t a n ~}$ \\ ${ }^{\text {g} H a z a r a ~ U n i v e r s i t y, ~ D e p a r t m e n t ~ o f ~ Z o o l o g y, ~ M a n s e h r a, ~ P a k i s t a n ~}$
}

\begin{abstract}
Salmo trutta fario is the most important fish species of family Salmonidae inhibited in cool waters all over the world including the nortern parts of Pakistan. This study was aimed to find out the prey selection and feeding habits of the species. One hundred and eighty five Salmo trutta fario were captured from March 2016 to April 2017. Feeding intensity as represented by a fullness index (FI), changing with various length groups and season. Out of 185 Brown trout 24 fish stomaches were found empty. The most important and common food items of brown trout were Brachycentridae, Blepharocera, Hydropsychidae, ephemerella spp. Kruskal Wallis H-test were applied on feeding intensity groups consisting of three month group. The test statistic for $\mathrm{K} . \mathrm{W}$-H-test were $(\mathrm{H}=8.13 \mathrm{with} \mathrm{df}=3)$ had a p-value of $0.043<$ (alpha $=0.05$ indicates favor of the alternative hypothesis of at least one difference among the feeding intensity groups. The linear relationship of $\mathrm{N}$ with index of relative importance and \%IRI denoted by least square regression line $(\mathrm{N}=35.2+22.1 \% \mathrm{IRI})$, shows that for 22 prey there is $1 \%$ change in IRI. The relationship between total length $(\mathrm{mm})$ and fish body weight $(\mathrm{gm})$ is expressed by Pearson correlation coefficient $(\mathrm{r}=0.976)$, showed that total length $(\mathrm{mm})$ and fish body weight (gm.) is highly correlated. Descriptive statistics are used for the stomach fullness, which shows that feeding intensity was recorded higher from March to May. A total of 2289 preys was recorded including the most common were; Trichoptera, Hydropsychidae, Brachycentridae, diptera, blepharocera, ephemerala, chironomida, honey bees, grass hopper, locust, trout egg, trochanter, plant tissue, stones were retrieved from the gut contents of brown trout. According to index of relative importance IRI\% four preys represents major components of the diet. The highest IRI\% was recorded in Brachycentridae (39.38\%), followed by blepharocera (13.23\%), Hydropsychidae (10.76\%) and ephemerella spp ( $8.28 \%)$. The relationship between IRI and FO is $(r=0.556)$ is moderately correlated with coefficient of determination $\left(r^{2}=0.31\right)$. This study will help in the development of an artificial diet for the species for better growth performance in captivity.
\end{abstract}

Keywords: hilly areas fish, cold water, fish of economic importance, Trichoptera, diet menu.

\section{Resumo}

Salmo trutta fario é a espécie de peixe mais importante da família dos salmonídeos, inibida em águas frias em todo o mundo, incluindo as partes do noroeste do Paquistão. Este estudo teve como objetivo conhecer a seleção de presas e os hábitos alimentares da espécie. Cento e oitenta e cinco Salmo trutta fario foram capturados de março de 2016 a abril de 2017. Intensidade de alimentação representada por um índice de plenitude (FI), mudando com vários grupos de comprimento e estação. De 185 trutas, 24 estômagos de peixes foram encontrados vazios. Os itens alimentares mais importantes e comuns da truta marrom foram brachycentridae, blepharocera, hydropsychidae, ephemerellaspp. $\mathrm{O}$ teste $\mathrm{H}$ de Kruskal Wallis foi aplicado em grupos de intensidade de alimentação consistindo de um grupo de três meses. A estatística de teste para o teste $\mathrm{KW}-\mathrm{H}$ foi $(\mathrm{H}=8,13 \mathrm{com} \mathrm{df}=3)$ teve um valor de $\mathrm{p}$ de $0,043<$ (alfa $=0,05$ indica favor da hipótese alternativa de pelo menos uma diferença entre os grupos de intensidade de alimentação. relação de $\mathrm{N}$ com o índice de importância relativa e\% IRI denotado pela linha de regressão do mínimo quadrado ( $\mathrm{N}=35,2+22,1 \%$ IRI), mostra que para 22 presas há $1 \%$ de mudança no IRI. A relação entre comprimento total $(\mathrm{mm})$ e peixes o peso corporal $(\mathrm{gm})$ é expresso pelo coeficiente de correlação de Pearson $(\mathrm{r}=0,976)$, mostrou

*e-mail: walikhan.pk@gmail.com

Received: June 6, 2020 - Accepted: September 23, 2020

This is an Open Access article distributed under the terms of the Creative Commons Attribution License, which permits unrestricted use, distribution, and reproduction in any medium, provided the original work is properly cited. 
que o comprimento total ( $\mathrm{mm}$ ) e o peso corporal dos peixes (gm.) são altamente correlacionados. Estatísticas descritivas são usadas para a plenitude do estômago, o que mostra que a intensidade da alimentação foi registrado mais alto de março a maio. Um total de 2.289 presas foi registrado, incluindo os mais comuns foram; trichoptera, hydropsychidae, brachycentridae, diptera, blepharocera, efemérala, chironomida, abelhas, funil de grama, gafanhoto, ovo de truta, trocânter, tecido vegetal, pedras foram retiradas do intestino conteúdo de truta marrom. De acordo com o índice de importância relativa IRI\%, quatro presas representam os principais componentes da dieta. O maior IRI\% foi registrado em brachycentridae (39,38\%), seguido por blepharocera $(13,23 \%)$, hydropsychidae $(10,76 \%)$ e ephemerellaspp (8,28\%). A relação entre IRI e FO é $(r=0,556)$ está moderadamente correlacionada com o coeficiente de determinação $(\mathrm{r} 2=0,31)$. Este estudo auxiliará no desenvolvimento de uma dieta artificial para a espécie para melhor desempenho de crescimento em cativeiro.

Palavras-chave: peixes de áreas montanhosas, peixes de água fria, peixes de importância econômica, tricópteros, cardápio de dieta

\section{Introduction}

Information on food and feeding habits of fish is very important for the artificial development in culture system which then provide a potential source of food. Brown trout closely related to Oncorhynchus mykiss (rainbow trout), Salve linus fontinalis (brook trout) and Salmo trutta labrax (sea trout). Rainbow trout occupied the cold waters of Swat, Dir, Chitral Shangla and Kohistan in Pakistan (Hassan et al., 2007). Socio-economically and tourist point of view this fish play a very vital role on commercial level (Butler et al., 2009). Salmonids are transporter of energy from lower to higher trophic levels therefore lies on the top-consumers list in freshwater environments (Karlsson and Byström, 2005).

Studies on ecto and endo parasitic fauna of snow trout of river Swat and river Panjkora have been published by Khalid et al. (2020) and Ahmad et al. (2020) while there is no study on food and feeding habit of the species. Before aquaculture of a particular fish species its needs to knows about their breeding, growth rate death rate, feeding habit (Piska and Naik, 2006). Feeding habit of a fish is essential as it does not shows its diets but also indicate relationship of various ecological components like behavior, habitat use, energy intake and inter/intra specific competition (Zachariah and Abdurahiman, 2010).

Brown trout can be cultured at high altitude of about 1000 meters above sea level this species was brought from Europe prior to rain bow trout which was introduced in 1928 in cold waters of N.W.F.P (Khyber Pakhtunkhwa) (Ahmad and Niazi, 1988). Rainbow trout can be culture easily as compare to brown trout because it can survive in high temperature and are like less carnivorous. The species having short hatching time as about 33 days and its growth rate is fast as compared to other cold water species (Hussain, 1994). Brown trout are opportunistic predator of insect and aquatic invertebrates, mollusk and bullies are present in the stomach of brown trout in natural environment (Grey, 2001). Brown trout also feed on other fishes hence prey and predator body components are same (Jonsson, 2001).The prey, predator relationship can be recognized through diet composition (Neveu, 1979). Salmo trutta L., 1758 (Brown trout) is an outstanding model organism to examine what aspects explain dietary behaviors, as its trophic ecology has been study in many areas. These studies reported difference in diet composition between populations. (Kara and Alp, 2005). Brown trout in open environment (river) eat worms small fish, mollusk, beetles, wasp, nymphs while in closed environment (hatchery) eat artificial prepared food which contain various ingredients i.e. soya bean meals, wheat flair, dry milk, soybean oil, fish meal, rice bran, vitamin mineral, vitamin premix and vitamin (Voorhees et al., 2019).

A number of factors affect the habitat of brown trout in natural environment like flood, industrial effluent, domestic sewage and agriculture run off, change in temperature and acidity of water also decrease the population of trout in natural environment (Ginetz and Larkin, 1976). Species population that are not naturally sympatric struggle for limited resources will occur in such population (Hearn, 1987). An vital mechanism through which the species decrease struggle is food resource separating, comprising both spatial and chronological distinction and modifications in feeding habits (Pianka, 1969; Schoener, 1974).The relationship between linked salmonid species magnifies the changes in using the habitat or resources of food (Blanchet et al., 2007; Dineen et al., 2007; SánchezHernández and Cobo, 2016).

Brown trout are nurturing on fishes mostly because of higher energy consumption and growth as a result of piscivorous behavior and hunting (Elliott and Hurley, 2000). Water temperature plays a major role amongst the abiotic factors that affect feeding, influences development, food ingestion and other activity (Ojanguren et al., 2001). Studying predator-prey relationships the prey feature investigation has been suggested to play a vital role (De Crespin de Billy and Usseglio-Polatera, 2002). Due to the lack of information about the feeding habit of the Brown trout the present study was plan to describes the diet composition of the species, and this study will help for aquaculturist to prepare artificial diet for better growth performance.

\section{Materials and Methods}

\subsection{Study area}

District Swat is located in the northern part of Pakistan. The temperature of the water bodies is from 5 to $-10 \mathrm{c}$ which is suitable for the survival of the trout. The fish samples were captured from various localities of upper reaches of the river as: Liakot, Peshmal, Asrait, Mankial and Bahrain (Akhtar, 1991). 


\subsection{Fish sampling and laboratory analysis}

Fish were collected from March 2016 to April 2017 with mesh net, gillnets, and trammel nets. The collection was based on monthly basis. The percentage number of fish were calculated from caught fish and their weight were calculated by using digital balance.

\subsection{Preservation}

Captured fish samples were preserved in 10\% formalin for further analysis.

\subsection{Identification of prey item}

The fish were preserved in container and tagged it indicating the name of each fish, collection site, date, and locality of the area. Total length, weight and gut content of the fish were recorded. Gut of fish was dissected in laboratory. Slides were prepared and observed under compound microscope. Retrieved various diet composition and weighted of full gut and empty gut were recorded in order to note the weight of the food in the stomach. Partially digested prey items were identified to the lowest taxonomic category.

\subsection{Data analysis}

\subsubsection{Fullness index}

Fullness index were calculated by using the following equation to show the feeding intensity (Equation 1),

$$
F I=\frac{\text { Wieght of the food }}{\text { Total wieght of fish }} * 100
$$

\section{Gastro Somatic Index (GSI):}

Feeding intensity of each fish can measure by calculating GSI by the following equation (Equation 2).

$$
\text { GSI }=\frac{\text { Total weight of the full gut }}{\text { Total weight of fish }} * 100
$$

Dietary importance of food category was determine by using index of relative importance (Pinkas, 1971).

$$
I R I=N \%+W \% * F O \%
$$

Where $\mathrm{FO} \%$ is the percentage frequency of occurrence of stomach in which food item is present relative to the total number of stomach containing food item. N\% is the numeric percentage of individual of food item relative to the total number of food item in the stomach, and W\% is the percentage of food item relative to the weight of total stomach contents. Percentage of weight (W \%) was used in place of volumetric percentage (Pita et al., 2002).

\section{Results}

A total of 2899 preys were retrieved from 185 brown trout stomachs and their average weight were $70.269 \mathrm{~g}$. The highest weight proportion of the diet was composed of Trichoptera (46.79\%), followed by Hydropsychidae
(44.16\%), Brachycentridae, (41.58). Ephemeroptera (12.082\%), Ephemerella spp (11.10\%), Coleoptera (9.335\%) and others i.e. locust, grasshopper, plant tissues, stones, (26.39\%) respectively. The most representative prey were Diptera (34.70\%), Trichoptera (33.87\%), Brachycentridae (29.32\%), Blepharocera (22.83\%) and others i.e. diphtheria, honey bee, grass hopper (16.86\%), and trochanter etc. and Ephemeroptera (11.52\%) respectively. According to IRI\% four item represent major components in diet composition, the most important among them are Brachycentridae (39.38\%), Blepharocerca (13.23\%), Hydropsychidae (10.76\%) and Ephemerlla spp (8.28\%) respectively listed in Table 1 (Equation 3).

In various diet components the percentage of $\mathrm{N}, \mathrm{W}, \mathrm{FO}$ and IRI are as i.e. Brachycentridae (\%N is 29.3 , \%W is 41.6 , \%FO is 9.2 and \%IRI is 39.8), in Hydropsychidae (\%N is 4.1, \%W is $4.6, \% \mathrm{FO}$ is 3.7 and \%IRI is 10.8$)$, in Chimara (\%N is $0.4, \% \mathrm{~W}$ is $0.6, \% \mathrm{FO}$ is 1.4 and \% RI is 0.1 ), in Ephemerella spp (\% $\mathrm{N}$ is $6.3, \% \mathrm{~W}$ is $11.1, \% \mathrm{FO}$ is 7.8 and \%IRI is 8.3 ), in Baetis spp (\%N is $5.2, \% \mathrm{~W}$ is $1.0, \% \mathrm{FO}$ is 8.3 and \%IRI is 0.6 ), in Chironomida (\% $\mathrm{N}$ is $9.9, \% \mathrm{~W}$ is $2.6, \% \mathrm{FO}$ is 5.3 and \%IRI is 4.0 ), in Chrysops (\% is $1.0, \% \mathrm{~W}$ is $0.6, \% \mathrm{FO}$ is 2.1 and \%IRI is 2.0), in Simulium (\%N is $1.0, \% \mathrm{~W}$ is 0.5 , \% FO is 1.6 and \%IRI is 0.2 ), in Blepharocera (\% $\mathrm{N}$ is $22.8, \% \mathrm{~W}$ is $0.1, \% \mathrm{FO}$ is 9.4 and \%IRI is 13.2), in Elemidae (\%N is 3.9, \%W is 9.3, \%FO is 6.2 and \%IRI is 5.0), in Coenagrionidae (\% is 0.8 , \%W is $1.2, \% \mathrm{FO}$ is 2.4 and \%IRI is 0.3 ), in Eurobodalla spp (\% $\mathrm{N}$ is $0.4, \% \mathrm{~W}$ is $0.3, \% \mathrm{FO}$ is 2.6 and \%IRI is 0.1 ), Dapthera (\% $\mathrm{N}$ is $5.7, \% \mathrm{~W}$ is $8.6, \% \mathrm{FO}$ is 10.6 and \%IRI is 9.2), Honey bee (\% is $0.7, \% \mathrm{~W}$ is $2.9, \% \mathrm{FO}$ is 8.8 and \%IRI is 1.9$)$, Grass hopper (\%N is $2.6, \% \mathrm{~W}$ is 4.6 , \%FO is 5.0 and \%IRI is 2.2 ), Locust (\%N is $2.8, \% \mathrm{~W}$ is $6.0, \% \mathrm{FO}$ is 5.9 and \%IRI is 3.2 ), Trochanter (\% is $1.4, \% \mathrm{~W}$ is $0.1, \% \mathrm{FO}$ is 4.0 and \%IRI is 0.4$)$, Trout eggs (\%N is $0.7, \% \mathrm{~W}$ is $2.0, \% \mathrm{FO}$ is 0.9 and \%IRI is 0.1 ), Plant tissues (\%N is $0.7, \% \mathrm{~W}$ is $0.7, \% \mathrm{FO}$ is 2.9 and \%IRI is 0.2 ) and Stones (\%N is $0.4, \% \mathrm{~W}$ is $1.5, \% \mathrm{FO}$ is 1.8 and \%IRI is 0.2 ). The graph shows the percentage of $\mathrm{N}, \mathrm{W}, \mathrm{FO}$ and IRI of various diet components in Figure 1.

In various length groups of brown trout fish, the GSI, Fullness Index (Equations 1 and 2), the total length of fish and weights of Gut and gut contents are listed in Table 2.

Table 3 shows the monthly variation of GSI and Fullness index in which there is a high GSI in May and the lowest in July, also there is a high fullness index in May and a lowest in December.

Monthly wise the total number of stomach studied and the percentages empty stomach are, in January $18.18 \%$, February 7.14\%, March 23.07, April 11.11\%, May 19.04\%, June $4 \%$, July 0\%, August $10.52 \%$, September $25 \%$, October $11.11 \%$, November $14.28 \%$ and December $25 \%$ respectively. Figure 2: also shows the no of stomach and empty stomach values on monthly basis.

The relationship of different variables are listed in table 4 . There is a positive correlation between $\mathrm{N}$ and $\mathrm{W}$ $(\mathrm{r}=0.711)$ with coefficient of determination $\left(\mathrm{r}^{2}=0.594\right)$, a moderate positive correlation between $\mathrm{FO}$ and $\mathrm{N}$ $(r=0.616)$ with coefficient of determination $\left(r^{2}=0.379\right)$. The relationship between $\mathrm{W}$ and FO with $(\mathrm{r}=0.468)$ is moderate positive correlated having strength of relationship with $\left(r^{2}=0.219\right)$. The relationship between IRI and $\mathrm{N}$ with $(r=0.893)$ is a positive perfectly correlated with coefficient 
Table 1. Food item and their relative importance index in the diet composition of brown trout.

\begin{tabular}{|c|c|c|c|c|c|c|c|c|}
\hline PREY & $\mathbf{N}$ & $\% N$ & w & \%W & FO & \%FO & IRI & \%IRI \\
\hline Trichoptera & 982 & 33.87 & 32.88 & 46.79 & 113 & 61.08 & 4926.7 & \\
\hline Brachycentridae & 850 & 29.32 & 29.22 & 41.58 & 73 & 39.45 & 2797.1 & 39.38 \\
\hline Hydropsychidae & 119 & 4.10 & 3.21 & 44.16 & 29 & 15.67 & 756.23 & 10.76 \\
\hline Chimera & 13 & 0.44 & 0.45 & 0.641 & 11 & 5.94 & 6.42 & 0.09 \\
\hline Ephemeroptera & 334 & 11.52 & 8.49 & 12.08 & 128 & 69.18 & 1632.7 & \\
\hline Ephemerellaspp & 182 & 6.27 & 7.80 & 11.10 & 62 & 33.51 & 582.06 & 8.28 \\
\hline Baetis Spp & 152 & 5.24 & 0.69 & 0.981 & 66 & 35.67 & 40.23 & 0.57 \\
\hline Diptera & 1006 & 34.70 & 2.698 & 3.839 & 147 & 79.45 & 3061.9 & \\
\hline Chironomida & 286 & 9.86 & 1.850 & 2.632 & 42 & 22.70 & 283.56 & 4.03 \\
\hline Chrysops & 28 & 0.96 & 0.448 & 0.637 & 17 & 9.189 & 14.67 & 0.20 \\
\hline Simulium & 30 & 1.034 & 0.33 & 0.469 & 13 & 7.027 & 10.56 & 0.15 \\
\hline Blepharocera & 662 & 22.83 & 0.07 & 0.099 & 75 & 40.54 & 929.54 & 13.23 \\
\hline Coleoptera & 112 & 3.86 & 6.56 & 9.335 & 49 & 26.48 & 349.40 & \\
\hline Elemidae & 112 & 3.86 & 6.56 & 9.335 & 49 & 26.48 & 349.40 & 4.97 \\
\hline Odonata & 23 & 0.73 & 0.87 & 1.23 & 19 & 10.27 & 20.12 & \\
\hline Coenagrionidae & 23 & 0.73 & 0.87 & 1.23 & 19 & 10.27 & 20.12 & 0.28 \\
\hline Hirudinea & 11 & 0.37 & 0.22 & 0.313 & 21 & 11.35 & 7.75 & \\
\hline Erobdellaspp & 11 & 0.37 & 0.22 & 0.313 & 21 & 11.35 & 7.75 & 0.11 \\
\hline Others & 431 & 14.86 & 18.55 & 26.39 & 317 & 171.35 & 7069.5 & \\
\hline Dapthera & 165 & 5.69 & 6.02 & 8.56 & 84 & 45.40 & 646.95 & 9.2 \\
\hline Honey Bee & 20 & 0.68 & 2.01 & 2.86 & 70 & 37.83 & 133.91 & 1.9 \\
\hline Grass Hopper & 75 & 2.58 & 3.23 & 4.59 & 40 & 21.62 & 155.14 & 2.2 \\
\hline Locust & 81 & 2.79 & 4.25 & 6.048 & 47 & 25.40 & 224.48 & 3.19 \\
\hline Trochanter & 40 & 1.37 & 0.1 & 0.142 & 32 & 17.29 & 26.14 & 0.37 \\
\hline Trout Eggs & 20 & 0.68 & 1.4 & 1.99 & 7 & 3.78 & 10.10 & 0.14 \\
\hline Plant Tissues & 19 & 0.65 & 0.50 & 0.17 & 23 & 12.43 & 16.91 & 0.24 \\
\hline Stones & 11 & 0.37 & 1.04 & 1.48 & 14 & 7.56 & 13.98 & 0.19 \\
\hline Total & 2899 & 194.7 & 70.26 & 186.3 & 794 & 445.99 & 7025.2 & 100.00 \\
\hline
\end{tabular}

Where $\mathrm{N}=$ Number, $\mathrm{W}=$ Weight, FO=Frequency of occurrence, IRI=Index of relative importance.

of determination $\left(\mathrm{r}^{2}=0.797\right)$. The relationship between IRI and W with $(\mathrm{r}=0.917)$ is strongly positive correlation having coefficient of determination $\left(r^{2}=0.840\right)$. The relationship between IRI and FO with ( $\mathrm{r}=0.556)$ is moderately positive correlated with coefficient of determination $\left(r^{2}=0.30\right)$. The Pearson correlation coefficient of Total length $(\mathrm{mm})$ and Fish body weight (gm.) is 0.976 (p-value $=0.02$ ).

The least square regression line $(N=35.2+22.1 \%$ IRI $)$ between number of Prey and \%IRI shows that if there is one percent change in IRI there will be 22 in prey number, it means that if 22 prey there will be one percent change in prey. Kruskal Wallis test were applied on feeding intensity the $\mathrm{H}$ statistic $(\mathrm{H}=8.13$ with $\mathrm{df}=3$ and $\mathrm{P}=0.043)$ indicates that on average the feeding intensity among different season is not equal there is at least one significant difference between feeding intensity among different groups. Figure 3 also shows the relationship.

\section{Discussion}

The presents study aimed to determine the prey selection and feeding habits of Salmo trutta fario (brown trout) in upper parts of river Swat, Pakistan and the data were taken from March 2016 to April 2017. During the study period a total of 185 guts of the brown trout were examined among a total of 2289 preys. Twenty four stomachs were found empty. Feeding intensity was represented by fullness index (FI), changing with various length groups and season. The most important food item of brown trout were Brachycentridae, Blepharocera, Hydropsychidae and ephemerella spp. The stomach fullness shows that feeding intensity was recorded higher from March to May. A total of 2289 preys mostly including; trichoptera, Hydropsychidae, Brachycentridae, diptera, blepharocera, ephemerala, chironomida, honey bees, grass hopper, locust, 


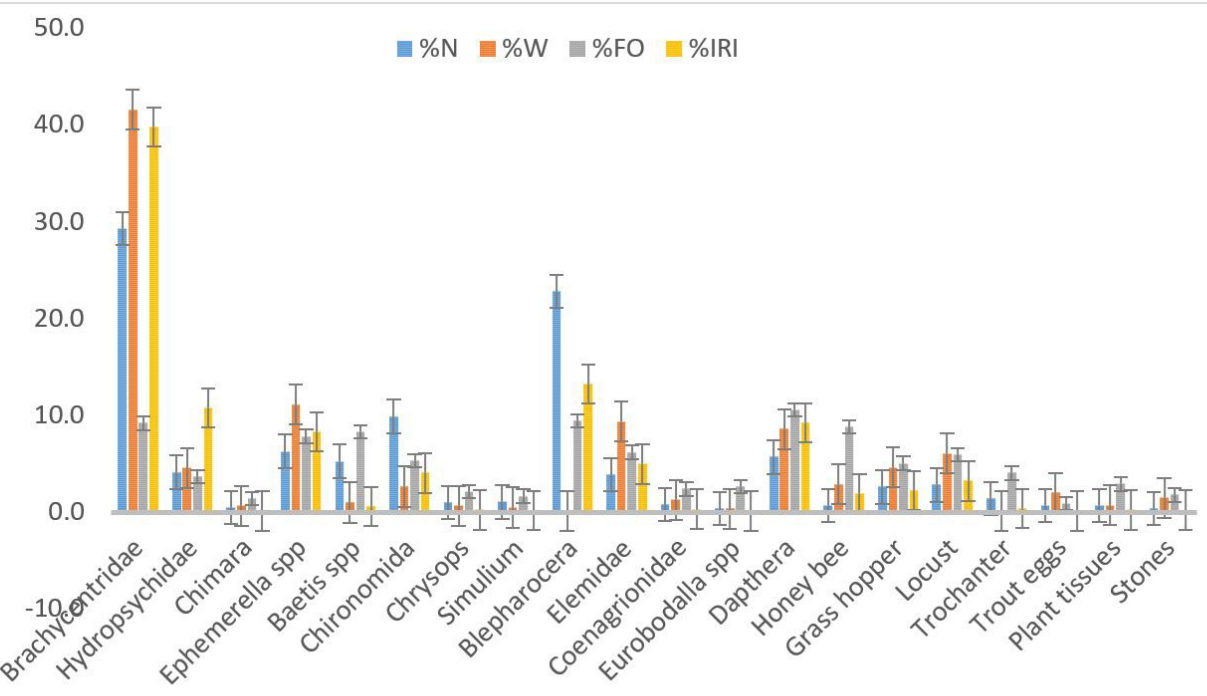

Figure 1. Percentage of N,W, FO and IRI of various diet components.

Table 2. GSI and fullness index of various length groups of brown trout.

\begin{tabular}{lccccc}
\hline \multicolumn{1}{c}{ Length $(\mathbf{m m})$} & $\mathbf{1 0 1 - 1 5 0}$ & $\mathbf{1 5 1 - 2 5 0}$ & $\mathbf{2 5 1 - 3 5 0}$ & $\mathbf{3 5 1 - 4 5 0}$ & Average \\
\hline Total length $(\mathrm{mm})$ & 126.2 & 170.3 & 301.2 & 402.1 & 249.9 \\
Fish body weight(gm) & 203 & 213 & 250 & 314 & 245 \\
Gut length $(\mathrm{mm})$ & 184.1 & 206.1 & 265 & 323.5 & 245.6 \\
Weight of full gut $(\mathrm{gm})$ & 41 & 52 & 77 & 84 & 63.5 \\
Weight of gut content $(\mathrm{g})$ & 19.5 & 22.3 & 42.5 & 51.1 & 33.8 \\
GSI & 20.19 & 24.41 & 28.4 & 26.75 & 24.9 \\
FI & 9.6 & 10.46 & 17 & 16.27 & 13.3 \\
\hline
\end{tabular}

Table 3. Relationship among FI and GSI on monthly basis.

\begin{tabular}{cllllllllllll}
\hline MONTH & JAN & FEB & MAR & APR & MAY & JUN & JUL & AUG & SEP & OCT & NOV & DEC \\
\hline GSI & 3.5 & 4.2 & 7.12 & 7.32 & 8.95 & 6.9 & 2.5 & 4.63 & 6.35 & 3.33 & 3.45 & 2.8 \\
FI & 1.28 & 1.47 & 2.95 & 3.02 & 3.11 & 2.35 & 2.61 & 1.81 & 1.25 & 1.01 & 1.031 & 0.815 \\
\hline
\end{tabular}

trout eggs, trochanters, plant tissues, stones were recovered from the gut contents of brown trout. According to index of relative importance (IRI \%) four preys represents major components of the diet. Food items and their relative importance Index in the diet composition of brown trout were present in the Table 1.

The highest IRI\% was recorded in Brachycentridae (39.38\%), followed by Blepharocera (13.23\%), Hydropsychidae (10.76\%), ephemerella spp (8.28\%) and presented in the Figure 1.Kruskal Wallis test were applied on feeding intensity the $\mathrm{H}$ statistic $(\mathrm{H}=8.13$ with $\mathrm{df}=3$ and $\mathrm{P}=0.043)$ indicates that on average the feeding intensity among different season is not equal there is at least one significant difference between feeding intensity among different groups. Figure 3 also shows the relationship between Feeding intensity and Length groups. Figure 4 also shows the graphical presentation of full gut weight and gut contents among various length groups
The study clearly showed that the most representative prey were dipteral (34.70\%) trichoptra (33.87\%) Brachycentridae (29.32\%) and blepharocera (22.83\%) By weight the large proportion of diet composed of trichoptra (46.79\%) Hydropsychidae (44.16\%) and Brachycentridae (41.58\%). Terrestrial insect numbers were increase during summer season and nymphs. During winter season because of their availability and similar diet have been identified from the trout living in the river of New Zealand (Burnet, 1969) and in France and in wales (Thomas, 1962; Elliott, 1973). The higher GSI value was in the month of April (7.32) and May (8.95) which indicate the large amount of food intake during these months and emphasized that when seasonal temperature arises the weight of ingested food item also increased (Elliott, 1973) The relationship between $\mathrm{N}$ and $\mathrm{W}$ is $(\mathrm{r}=0.711)$ is positive correlation with coefficient of determination $\left(r^{2}=0.594\right)$. The relationship between FO and $\mathrm{N}$ is $(\mathrm{r}=0.616)$ is moderate 


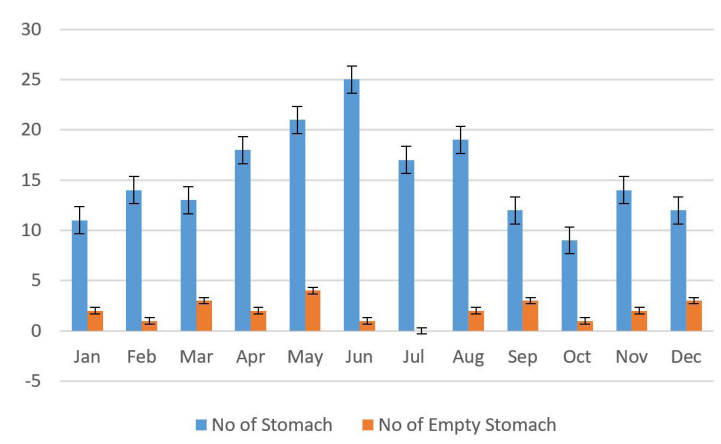

Figure 2. Month wise number of stomach and empty stomachs.

Table 4. Pearson correlation between prey N, W, FO and IRI.

\begin{tabular}{crcc}
\hline & N & W & FO \\
\hline W & $0.771(0.594)$ & & \\
FO & $0.6160 .379)$ & $0.468(0.219)$ & \\
IRI & $0.8930 .797)$ & $0.917(0.840)$ & $0.556(0.309)$ \\
\hline
\end{tabular}

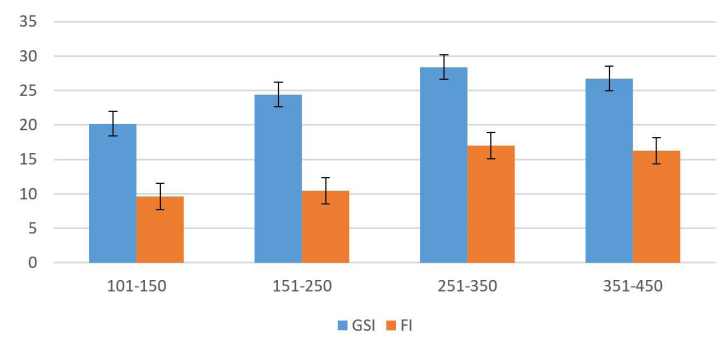

Figure 3. Relationship between feeding intensity and length groups.

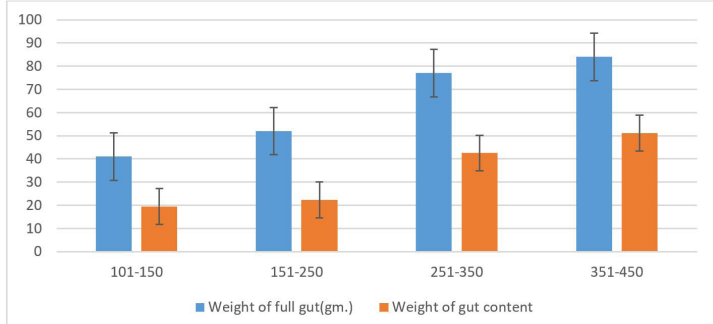

Figure 4. Full gut weight and gut contents among various length groups.

positive correlation with coefficient of determination $\left(\mathrm{r}^{2}=0.379\right)$.The relationship between $\mathrm{W}$ and $\mathrm{FO}$ is $(\mathrm{r}=0.468)$ is moderate positive correlation with coefficient of determination $\left(r^{2}=0.219\right)$.The relationship between IRI and $\mathrm{N}$ is $(\mathrm{r}=0.893)$ is strong positive correlation with coefficient of determination $\left(r^{2}=0.797\right)$.The relationship between IRI and $\mathrm{W}$ is $(\mathrm{r}=0.917)$ is strong positive correlation with coefficient of determination $\left(\mathrm{r}^{2}=0.840\right)$.The relationship between IRI and FO is ( $r=0.556)$ is moderate positive correlation with coefficient of determination $\left(r^{2}=0.309\right)$.

It was concluded that brown trout is the principal species of family Salmonidae inhibited in cool water bodies of the study areas. Gut contents of brown trout were analyzed on monthly basis. Present study will help in the development of an artificial diet for better growth in captivity for the members of the family Salmonidae. In the present findings some quantity of sand also observed from the stomach which shows their benthic feeding habit. This study was further supported from the research of (Richardson, 1993) who suggested that bathetic production have confined the salmons production.

\section{References}

AHMAD, M.F. and NIAZI, M.S., 1988. Important edible fishes of Pakistan. Rome: FAO. 31 p.

AHMAD, A., KHAN, W., DAS, S.N., PANHWAR, W.A., KHALID,S., MEHMOOD,S.A., AHMED, S., KAMAL,M., AHMED, M.S., UL HASSAN, H., ZAHOOR, S., and MAQBOOL, A., 2020. Assessment of ecto and endo parasites of Schizothorax plagiostomus inhabiting river Panjkora, Khyber Pakhtunkhwa, Pakistan. Brazilian Journal of Biology, In press. https://doi.org/10.1590/1519-6984.222214.

AKHTAR, N., 1991. The Northern Areas (Pakistan). Fisheries profile, feasible sites for trout culture and an overall sector development perspective. Report for Project PAK/91/008. Rome: FAO.

BLANCHET, S., LOOT, G., GRENOUILLET, G. and BROSSE, S., 2007. Competitive interactions between native and exotic salmonids: a combined field and laboratory demonstration. Ecology Freshwater Fish, vol. 16, no. 2, pp. 133-143. http://dx.doi. org/10.1111/j.1600-0633.2006.00205.x.

BURNET, A.M.R., 1969. A study of the inter-relation between eels and trout, the invertebrate fauna and the feeding habits of the fish. New Zealand: New Zealand Marine Department.

BUTLER, J.R., RADFORD, A., RIDDINGTON, G. and LAUGHTON, R., 2009. Evaluating an ecosystem service provided by Atlantic salmon, sea trout and other fish species in the River Spey, Scotland: the economic impact of recreational rod fisheries. Fisheries Research, vol. 96, no. 2-3, pp. 259-266. http://dx.doi. org/10.1016/j.fishres.2008.12.006.

DE CRESPIN DE BILLY, V. and USSEGLIO-POLATERA, P., 2002. Traits of brown trout prey in relation to habitat characteristics and benthic invertebrate communities. Journal of Fish Biology, vol. 60, no. 3, pp. 687-714. http://dx.doi.org/10.1111/j.1095-8649.2002.tb01694.x.

DINEEN, G., HARRISON, S.S.C. and GILLER, P.S., 2007. Diet partitioning in sympatric Atlantic salmon and brown trout in streams with contrasting riparian vegetation. Journal of Fish Biology, vol. 71, no. 1, pp. 17-38. http://dx.doi.org/10.1111/j.1095-8649.2007.01441.x.

ELLIOTT, J.M. and HURLEY, M.A., 2000. Daily energy intake and growth of piscivorous brown trout, Salmo trutta. Freshwater Biology, vol. 44, no. 2, pp. 237-245. http://dx.doi.org/10.1046/ j.1365-2427.2000.00560.x.

ELLIOTT, J.M., 1973. The food of brown and rainbow trout (Salmo trutta and S. gairdneri) in relation to the abundance of drifting invertebrates in a mountain stream. Oecologia, vol. 12, no. 4, pp. 329-347. http://dx.doi.org/10.1007/BF00345047. PMid:28308235.

GINETZ, R.M. and LARKIN, P.A., 1976. Factors affecting rainbow trout (Salmo gairdneri) predation on migrant fry of sockeye salmon (Oncorhynchus nerka). Journal of the Fisheries Board of Canada, vol. 33, no. 1, pp. 19-24. http://dx.doi.org/10.1139/f76-003.

GREY, J., 2001. Ontogeny and dietary specialization in brown trout (Salmo trutta L.) from Loch Ness, Scotland, examined using stable isotopes of carbon and nitrogen. Ecology Freshwater Fish, vol. 10, no. 3, pp. 168-176. http://dx.doi.org/10.1034/j.16000633.2001.100306.x.

HASSAN, A., ISHAQ M., FAROOQ A. and SADOZAI, S.H., 2007. Economics of trout fish farming in the northern areas of Pakistan. Sarhad Journal of Agriculture, vol. 23, no. 2, pp. 407. 
HEARN, W.E., 1987. Interspecific competition and habitat segregation among stream-dwelling trout and salmon: a review. Fisheries (Bethesda, Md.), vol. 12, no. 5, pp. 24-31. http://dx.doi. org/10.1577/1548-8446(1987)012<0024:ICAHSA>2.0.CO;2.

HUSSAIN, K.A., 1994. Some fish species for use in aquaculture in Pakistan. In Proceedings of National Seminar on Fisheries Policy and Planning, 1994, Karachi. Karachi: Marine Fisheries Department, Government of Pakistan, pp. 332-339.

JONSSON, S., 2001. Stocking of Brown Trout (Salmo trutta L.): factors affecting survival and growth. Umeå: Swedish University of Agricultural Sciences, 22 p. Doctoral dissertation. Acta Universitatis Agriculturae Sueciae. Silvestria 230.

KARA, C. and ALP, A., 2005. Feeding habits and diet composition of brown trout in the upper streams of River Ceyhan and River Euphrates in Turkey. Turkish Journal of Veterinary and Animal Sciences, vol. 29, pp. 417-428.

KARLSSON, J. and BYSTRÖM, P., 2005. Littoral energy mobilization dominates energy supply for top consumers in subarctic lakes. Limnology and Oceanography, vol. 50, no. 2, pp. 538-543. http:// dx.doi.org/10.4319/lo.2005.50.2.0538.

KHALID, S., KHAN, W., DAS, S.N., AHMAD, A., MEHMOOD, S.A., PAHANWAR, W.A., AHMED, S., KAMAL, M., WAQAS, M., WAQAS, R.M., HASSAN, H.U., ZAHOOR, S. and MAQBOOL, A., 2020. Evaluation of ecto and endo parasitic fauna of Schizothorax plagiostomus inhabitants of river Swat, Khyber PakhtunKhwa, Pakistan. Brazilian journal of biology = Revista brasleira de biologia. http://dx.doi.org/10.1590/1519-6984.222215. PMid:32578670.

NEVEU, A., 1979. Les problèmes posés par l'étude de l'alimentation naturelle des populations sauvages de poissons. Bulletin du Centre d'Etudes et de Recherches Scientifiques Biarritz, Vol. 12, No. 3, pp. 501-512.

OJANGUREN, A.F., REYES-GAVILÁN, F.G. and BRAÑA, F., 2001. Thermal sensitivity of growth, food intake and activity of juvenile brown trout. Journal of Thermal Biology, vol. 26, no. 3, pp. 165-170. http://dx.doi.org/10.1016/S0306-4565(00)000383. PMid: 11240221.
PIANKA, E.R., 1969. Sympatry of desert lizards (Ctenotus) in Western Australia. Ecology, vol. 50, no. 6, pp. 1012-1030. http://dx.doi. org/10.2307/1936893.

PINKAS, L., 1971. Food habits study. Food habits of albacore bluefin tuna and bonito in California waters. Fish Bulletin, vol. 152, pp. 1-105.

PISKA, R.S. and NAIK, S.J., 2006. Fish biology and ecology (fisheries). Hyderabad: University Collage of Science, Osmania University.

PITA, C., GAMITO, S. and ERZINI, K., 2002. Feeding habits of the gilthead seabream (Sparus aurata) from the Ria Formosa (southern Portugal) as compared to the black seabream (Spondyliosoma cantharus) and the annular seabream (Diplodus annularis). Journal of Applied Ichthyology, vol. 18, no. 2, pp. 81-86. http://dx.doi.org/10.1046/j.1439-0426.2002.00336.x.

RICHARDSON, J.S., 1993. Limits to productivity in streams: evidence from studies of macroinvertebrates. Canadian Special Publication of Fisheries and Aquatic Sciences, pp. 9-15.

SÁNCHEZ-HERNÁNDEZ, J. and COBO, F., 2016. Ontogenetic shifts in terrestrial reliance of stream-dwelling brown trout. Journal of Limnology, vol. 75, no. 2, pp. 409-414. http://dx.doi.org/10.4081/ jlimnol.2016.1322.

SCHOENER, T.W., 1974. Resource partitioning in ecological communities. Science, vol. 185, no. 4145, pp. 27-39. http://dx.doi. org/10.1126/science.185.4145.27. PMid:17779277.

THOMAS, J.D., 1962. The food and growth of brown trout (Salmo trutta L.) and its feeding relationships with the salmon parr (Salmo salar L.) and the eel (Anguilla anguilla (L.)) in the River Teify, West Wales. Journal of Animal Ecology, vol. 31, no. 2, pp. 175-205. http://dx.doi.org/10.2307/2136.

VOORHEES, J.M., BARNES, M.E., CHIPPS, S.R., BROWN, M.L. and GONZÁLEZ-REDONDO, P., 2019. Bioprocessed soybean meal replacement of fish meal in rainbow trout (Oncorhynchus mykiss) diets. Cogent Food \& Agriculture, vol. 5, no. 1, pp. 1579482. http:// dx.doi.org/10.1080/23311932.2019.1579482.

ZACHARIAH, P. U. and ABDURAHIMAN, K. P., 2010. Method of stomach content analysis of fishes. Mangalore: Central Marine Fisheries Research Institute. 